\title{
PENGARUH KOMITMEN, KREATIVITAS DAN WFH TERHADAP KINERJA GURU (SELAMA PANDEMI COVID 2019 WR SUPRATMAN 2)
}

\author{
Dian Saputra Harahap ${ }^{1)}$, Fenny Krisna Marpaung ${ }^{2)}$ \\ ${ }^{1,2)}$ Manajemen, Universitas Prima Indonesia \\ e-mail: dianhrp493@gmail.com
}

Penelitian ini bertujuan menganalisis dampak komitmen, kreativitas dan WFH terhadap kinerja guru selama pandemi covid 2019 WR Supratman 2. Populasi berjumlah 150 orang dan sampel dalam penelitian ini berjumlah 109 orang. Pengujian menggunakan teknik analisis linear berganda hasil uji hipotesis secara parsial didapat bahwa komitmen memiliki nilai $t_{\text {hitung }}>t_{\text {tabel }}$ yaitu $2,953>1,65950$ dengan taraf signifikan 0,004 $<0,05$, kreativitas memiliki nilai $t_{\text {hitung }}>t_{\text {tabel }}$ yaitu 2,916 > 1,65950 dengan taraf signifikan 0,004 $<0,05$ dan WFH memiliki nilai $t_{\text {hitung }}>t_{\text {tabel }}$ yaitu 7,464 > 1,65950 dengan taraf signifikan $0,000<0,05$ sehingga komitmen, kreattivitas dan WFH berpengaruh positif dan signifikan terhadap kinerja guru WR Supratman 2. Hasil pengujian secara simultan didapat bahwa nilai $F_{\text {hitung }}>F_{\text {tabel }}$ sebesar 329,188 > 2,69 dengan taraf signifikan 0,000 $<0,05$ sehingga diambil kesimpulan bahwa komitmen, kreativitas dan WFH berpengaruh dan signifikan secara bersama-sama terhadap kinerja guru WR Supratma 2. Perolehan pengujian koefisien determinasi didapat nilai adjusted $r$ square sebesar 0,901 atau sebesar 90,1\% yang artinya bahwa komitmen, kreativitas dan WFH hanya menjelaskan variasi variabel kinerja guru sebesar 90,1\% dan sisanya 9,9\% dipengaruhi oleh variabel lain diluar variabel penelitian ini.

Kata Kunci : Kinerja Guru, Komitmen, Kreativitas dan WFH

\begin{abstract}
This study aims to analyze the impact of commitment, creativity and WFH on teacher performance during the 2019 covid pandemic WR Supratman 2. The population is 150 people and the sample in this study is 109 people. Tests using multiple linear analysis techniques, the results of the hypothesis test partially show that commitment has a value of tcount > ttable, namely 2.953> 1.65950 with a significant level of $0.004<0.05$, creativity has a value of tcount > ttable that is 2.916> 1.65950 with a significant level of $0.004<0.05$ and WFH has a value of tcount > ttable which is $7.464>1.65950$ with a significant level of $0.000<0.05$ so that commitment, creativity and WFH have a positive and significant effect on the performance of WR Supratman 2. The results of the simultaneous test show that the value of Fcount > Ftable of $329.188>2.69$ with a significant level of $0.000<0.05$ so it can be concluded that commitment, creativity and WFH have an effect and are significant together on the performance of WR Supratma teachers. or $90.1 \%$, which means that commitment, creativity and WFH only explain variations in teacher performance variables ar $90.1 \%$ and the remaining $9.9 \%$ is influenced by other variables outside the variables of this study.
\end{abstract}

Keywords : Comitment, Creativity, Teacher Performance, WFH

\section{PENDAHULUAN}

Guru memegang peranan penting dalam dunia pendidikan, sebagai seorang guru mempunyai tugas dan tanggung jawab yang berat untuk mendidik, mengajar, melatih dan 
membimbing anak didik dalam mencapai hasil yang lebih baik, prestasi yang cemerlang dan mendapatkan nilai yang memuaskan. Kinerja guru sangat berhubungan dengan kualitas guru dalam menjalankan tugasnya seperti bekerja dengan siswa secara individual, persiapan dan perencanaan pembelajaran, pendayagunaan media pembelajaran, melibatkan siswa dalam berbagai pengalaman pembelajaran dan kepemimpinan yang aktif dari guru. Kinerja guru bisa tercapai dengan baik tentu perlu berbagai faktor pendukung seperti serta komitmen organisasi yaitu Sekolah dimana guru itu bertugas dan pemerintah.

Penyebab kinerja guru yang masih kurang adalah kurangnya dalam memahami kemajuan teknologi terutama dibidang informasi. Masih ada pula guru yang melaksanakan pembelajaraan yang terlalu teks book dengan buku paket dan kurang mempertimbangkan sumber (referensi yang lain). Disisi lain adalah masih ada guru yang tidak membuat rencana pembelajaran, masih kurang minat seorang guru untuk mengembangkan profesinya, masih ada guru yang kurang pandai menciptakan suasana kelas yang kondusif, karena masih ada kelas yang ribut pada saat pelajaran berlangsung, dan masih banyak pula guru yang tidak mampu menguasai kelas. Ini terlihat dari masih adanya beberapa siswa yang berada diluar kelas, atau bahkan dikantin saat jam pelajaran.

Dalam masa pandemic covid 19 ini komitmen yang rendah terjadi karena banyaknya siswa siswi dalam proses belajar mengajar tidak mengikuti kegiatan belajar online, keterlambatan mahasiswa dalam mengirim tugas online serta strategi guru yang masih kurang dalam memberikan materi pembelajaran online. Dalam belajar banyak siswa-siswi yang kurang memperhatikan guru pada waktu menyampaikan materi pembelajaran pada saat proses belajar mengajar online.

Kreativitas seorang guru yang masih kurang dalam masa pandemic covid 19 ini seperti halnya guru tidak dapat melakukan inovasi yang baik seperti tidak mampu dalam membuat video pembelajaran, kurang memahami dalam memberikan materi pembelajaran melalui daring secara online, kurang dalam mencari sumber belajar online yang menarik.

Adanya kasus covid 19 ini menjadi fenomena yang penting didalam dunia pendidikan dimana virus ini banyak memakan korban jiwa sehingga mengharuskan seluruh anak didik belajar dari rumah maupun guru mengajar dari rumah atau yang disebut dengan WFH agar mengurangi angka kematian. Namun ada banyak berbagai kendala yang dihadapi anak didik maupun seorang guru yaitu dalam penggunaan alat teknologi seperti Hanphone, karena kurangnya memahami teknologi maupun jaringan yang dimiliki anak didik yang tidak stabil sehingga mengakibatkan sistem proses belajar mengajar yang lambat sehingga kinerja guru krang dalam melatih maupun mendidik anak didik tersebut.

\section{KAJIAN PUSTAKA Komitmen}

Komitmen organisasional adalah perasaan sikap, dan perilaku individu mengidentifikasikan dirinya sebagai bagian dari oganisasi dan loyl terhadap organisasi dalam mencapai tujuan organisasi (Wibowo 2017:214). Menurut Joharis, Indra (2019:21), kinerja akan semakin baik bila komitmen semakin tinggi pada apa yang menjadi tanggung jawab terhadapa diri sendiri, siswa dan sekolah. Artinya guru memiliki komitmen yang tinggi akan menunjukkan perhatian yang kuat pada prestasi kerjanya dalam melaksanakan tindakan yang diperlukan untuk mencapai tujuan. Indikator dari komitmen terbagi atas (Wibowo $2017: 215$ ):

1. Komitmen Afektif

2. Komitmen Berkelanjutan

3. Komitmen Normatif 


\section{Kreativitas}

Kreativitas merupakan kemampuan seseorang untuk menciptakan, memadukan pemikiran dan imajinasi sehingga menghasilkan sesuatu yang bersifat original baik berupa ide-ide, kegiatan dan performa unik yang dapat menarik minat banyak orang. (Jasa Ungguh Muliawan, 2016 :3). Menurut penelitian Lasalu (2015:4), menyebutkan bahwa kreativitas guru berperan dalam meningkatkan hasil belajar siswa. Hal ini karena guru menggunakan metode yang bervariasi esuai materi yang diajarkan, sehingga menciptakan suasana belajar yang aktif dan menyenangkan. Indikator dari kreativitas adalah sebagai berikut:

1. Terampil dalam mengelola kelas.

2. Memiliki rasa empatik terhadap peserta didik.

3. Terampil membuat instrument soal yang baik.

\section{WFH}

Pekerjaan dan tugas yang dilakukan dari jarak jauh yaitu dari rumah tangga perlu dipahami tidak hanya dalam kategori defenisi tetapi terutama dalam kategori praktik : bekerja dirumah berarti mengalami dua dunia (privat dan publik, keluarga dan pekerjaan ) secara bersamaan dengan ruang terbatas. (Gadecki,et al.,2018). Menurut Putri,dkk (2020) kendala dari proses belajar mengajar online dirumah sebagai hasil dari situasi yang belum pernah terjadi sebelumnya dengan pandemi Covid 19 sehingga kinerja guru kurang optimal.Menurut Arwen,dkk (2020), bahwa dampak belajar dirumah juga dirasakan oleh orang tua juga memiliki beban lebih karena harus menjadi guru dirumah, mengajar membuat tugas dan selalu memantau. Dengan indikator sebagai berikut:

1. Ruang

2. Waktu

3. Peran sosial

\section{Kinerja Guru}

Kinerja adalah hasil kerja yang telah dicapai seseorang dari tingkah laku kerjanya dalam melaksanakan aktivitas kerja. Kinerja sendiri mengacu pada kadar pencapaian tugas yang membentuk sebuah pekerjaan. (Sutrisno 2016:151). Menurut (Supardi, 2016:59-69) dengan indikator sebagai berikut:

1. Perencanaan Pembelajaran

2. Proses Pembelajaran

3. Melakukan Penilaian Pembelajaran

\section{METODE PENELITIAN}

\section{Metode Penelitian}

\section{Pendekatan Penelitian}

Pendekatan penelitian ini berdasarkan pendekatan kuantitatif. Menurut Sugiyono (2012:7) penelitian kuantitatif adalah model penelitian dengan menggunakan angka-angka sebagai hasil statistik yang akan diuji.

\section{Jenis Penelitian}

Jenis penelitian ini merupakan jenis penelitian deskriptif. Menurut sujarweni (2015:49), "penelitian deskriptif adalah penelitian yang dilakukan utuk mengetahui nilai dari masing-masing variabel yang diuji baik satu variabel maupun lainnya tanpa membuat perbandingan dengan variabel yang tidak diteliti."

\section{Populasi dan Sampel Penelitian}

Menurut Sugiyono (2013:115) Populasi adalah keseluruhan dari objek yang akan diteliti. Adapun yang menjadi populasi penelitian ini adalah seluruh guru yang ada di yayasan Wr Supratman yang berjumlah 150 orang. 
Menurut Sugiyono (2013:116) sampel adalah bagian dari jumlah dan karakteristik yang dimiliki oleh populasi tersebut. Besarnya jumlah sampel dalam penelitian ini, maka peneliti menggunakan rumus Slovin untuk memperkecil jumlah populasi, hal tersebut dikarenakan keterbatasan waktu, biaya dan tenaga peneliti berikut adalah rumus yang digunakan, yaitu :

$$
\begin{aligned}
\mathrm{n} & =\frac{\mathrm{N}}{1+\left(\mathrm{N}^{2} \mathrm{e}^{2}\right)} \\
& =\frac{150}{1+150(0.05)^{2}} \\
& =109 \text { orang }
\end{aligned}
$$

\section{Teknik Pengumpulan Data}

Dalam pemilihan teknik pengumpulan data harus cermat. Teknik pengumpulan data yang digunakan dalam penelitian ini adalah:

1. Angket

2. Wawancara

3. Studi Dokumentasi

\section{Jenis dan Sumber Data}

Menurut jenisnya data yang digunakan dalam penelitian ini yaitu jenis data kuantitatif. sumber data dalam penelitian ini terdiri atas :

a) Data Primer

b) Data Sekunder

\section{Uji Validitas Dan Reliabilitas Instrumen Variabel}

Uji Validitas

Menurut Sujarweni (2014:192) uji validitas digunakan untuk mengetahui kelayakan butir-butir dalam suatu daftar pertanyaan dalam mendefenisikan suatu variabel.

1. Jika $r_{\text {hitung }}>r_{\text {tabel }}(0,361)$ dan nilai signifikan $<0,05$ maka pertanyaan dinyatakan valid.

2. Jika $r_{\text {hitung }}<r_{\text {tabel }}(0,361)$ dan nilai signifikan $<0,05$ maka pertanyaan dinyatakan tidak valid.

\section{Uji Reliabilitas}

Dalam penelitian ini, peneliti menggunakan metode Cronbach's Alpha. Untuk pengujian, batasan yang digunakan adalah 0,60. Artinya kriteria suatu instrument dikatakan reliable yaitu:

1. Cronbach's alpha $<0,6=$ reliabilitas buruk

2. Cronbach's alpha $0,6-0,79=$ reliabilitas diterima.

3. Cronbach's alpha $0,8=$ reliabilitas baik

\section{Uji Asumsi Klasik}

Uji asumsi klasik yang dijalankan meliputi dari uji normalitas, uji multikolinieritas, serta uji heteroskedastisitas. Adapun pengujian asumsi klasik dilakukan melalui softwareSPSS 20.

\section{Model analisis Data Penelitian \\ Model Penelitian}

Penelitian ini melalui penggunaan analisa regresi linear berganda. Model regresi linear berganda yang dipergunakan ialah:

Keterangan :

$$
\mathrm{Y}=\mathrm{a}+\mathrm{b}_{1} \mathrm{X}_{1}+\mathrm{b}_{2} \mathrm{X}_{2}+\mathrm{b}_{3} \mathrm{X}_{3}++\mathrm{e}
$$

Y : Kinerja Guru

a : Konstanta 
$\mathrm{b}_{1,2,3,4}$ : besaran koefisien regresi $\mathrm{X}$

$\mathrm{X}_{1} \quad$ : Komitmen

$\mathrm{X}_{2} \quad$ : Kreativitas

$\mathrm{X}_{3} \quad: \mathrm{WFH}$

e $\quad$ : standar error $(\alpha=5 \%)$

\section{Koefisien Determinasi}

Ghozali (2016:95) mengatakan koefisien determinasi Adjusted $R$ Square bertujuan untuk menghitung sejauh mana kemampuan model untuk menjelaskan variabel yang bebas.

\section{Pengujian Hipotesis Secara Simultan(Uji F)}

Ghozali (2016:96) mengungkapkan uji statistik F umumnya memperlihatkan apakah seluruh variabel bebasa yang masuk ke dalam model memiliki pengaruh secara simultan bagi variabel terikat. Dengan kriteria pengambilan keputusannya adalah :

Jika $\mathrm{F}_{\text {hitung }}<\mathrm{F}_{\text {tabel }}$, maka $\mathrm{H}_{0}$ diterima dan Ha ditolak, pada $\alpha=0,05$

$\mathrm{F}_{\text {hitung }}>\mathrm{F}_{\text {tabel }}$, maka $\mathrm{H}_{0}$ ditolak dan Ha diterima, pada $\alpha=0,05$

\section{Pengujian Hipotesis Secara Parsial (Uji t)}

Ghozali (2016:97) mengungkapkan pengujian statistik t pada umunya membutikan sejauh apa pengaruh suatu variabel penjelas atau terikat dengan individual untuk menjelaskan variasi variabel bebas. Dengan kriteria pengambilan keputusannya adalah:

Jika $-\mathrm{t}_{\text {tabel }} \leq \mathrm{t}_{\text {hitung }} \leq \mathrm{t}_{\text {tabel }} ;$ maka $\mathrm{H}_{0}$ diterima dan Ha ditolak, pada $\alpha=0,05$

$t_{\text {hitung }}<-t_{\text {tabel }}$ atau $t_{\text {hitung }}>t_{\text {tabel }} ;$ maka $\mathrm{H}_{0}$ ditolak dan Ha diterima, pada $\alpha=0,05$

\section{HASIL DAN PEMBAHASAN}

\section{Uji Validitas}

Untuk mengetahui kelayakan dari jumlah dalam daftar pertanyaan (angket) yang telah disajikan pada responden maka perlu dilakukan dengan uji validitas. Dapat dikatakan valid jika $r_{\text {hitung }}>$ dari $r_{\text {tabel }}$ atau validitas setiap pertanyaan lebih besar dari 0,30 maka data dapat dikatakan valid.

Tabel III.2. Uji Validitas Komitmen

\begin{tabular}{|l|r|r|r|r|}
\hline & $\begin{array}{c}\text { Scale Mean if } \\
\text { Item Deleted }\end{array}$ & $\begin{array}{c}\text { Scale Variance } \\
\text { if Item Deleted }\end{array}$ & $\begin{array}{c}\text { Corrected Item- } \\
\text { Total } \\
\text { Correlation }\end{array}$ & $\begin{array}{c}\text { Cronbach's } \\
\text { Alpha if Item } \\
\text { Deleted }\end{array}$ \\
\hline X1.1 & 24,61 & 20,482 &, 687 &, 876 \\
X1.2 & 24,52 & 19,474 &, 819 &, 863 \\
X1.3 & 24,88 & 21,958 &, 544 &, 888 \\
X1.4 & 24,88 & 21,328 &, 536 &, 889 \\
X1.5 & 24,53 & 19,177 &, 671 &, 878 \\
X1.6 & 24,62 & 18,663 &, 793 &, 864 \\
X1.7 & 25,06 & 20,116 &, 578 &, 887 \\
X1.8 & 24,75 & 19,799 &, 738 &, 871 \\
\hline
\end{tabular}

Sumber : Hasil Penelitian,2021(Data Diolah)

Berdasarkan Tabel III.2 diatas menunjukkan bahwa nilai $r_{\text {hitung }}$ lebih besar dari 0,30 maka data pada variabel komitmen dikatakan valid, dan nilai validitas terdapat pada kolom corrected item-Total yang artinya nilai korelasi antara skor setiapbutir dengan skor total pada tabulasi jawaban responden. Sehingga dari masing- masing pertanyaan sebanyak 8 
pertanyaan pada ruang lingkup Sekolah Wr Supratman 2. Sehingga data yang diperoleh juga layak untuk digunakan untuk pengujian lebih lanjut yaitu reliabilitas.

Tabel 1. Uji Validitas Kreativitas

Item-Total Statistics

\begin{tabular}{|l|r|r|r|r|}
\hline & $\begin{array}{c}\text { Scale Mean if } \\
\text { Item Deleted }\end{array}$ & $\begin{array}{r}\text { Scale Variance } \\
\text { if Item Deleted }\end{array}$ & $\begin{array}{c}\text { Corrected Item- } \\
\text { Total } \\
\text { Correlation }\end{array}$ & $\begin{array}{c}\text { Cronbach's } \\
\text { Alpha if Item } \\
\text { Deleted }\end{array}$ \\
\hline X2.1 & 24,83 & 22,127 &, 751 &, 868 \\
X2.2 & 24,98 & 23,518 &, 633 &, 880 \\
X2.3 & 24,99 & 22,083 &, 801 &, 863 \\
X2.4 & 24,91 & 23,325 &, 790 &, 866 \\
X2.5 & 24,98 & 23,203 &, 800 &, 865 \\
X2.6 & 25,34 & 25,708 &, 389 &, 903 \\
X2.7 & 25,16 & 23,651 &, 667 &, 877 \\
X2.8 & 25,31 & 24,791 &, 546 &, 888 \\
\hline
\end{tabular}

Sumber : Hasil Penelitian,2021(Data Diolah)

Berdasarkan Tabel 1diatas menunjukkan bahwa nilai rhitung lebih besar dari 0,30 maka data pada variabel kreativitas dikatakan valid, dan nilai validitas terdapat pada kolom corrected item-Total yang artinya nilai korelasi antara skor setiapbutir dengan skor total pada tabulasi jawaban responden. Sehingga dari masing- masing pertanyaan sebanyak 8 pertanyaan pada ruang lingkup Sekolah Wr Supratman 2. Sehingga data yang diperoleh juga layak untuk digunakan untuk pengujian lebih lanjut yaitu reliabilitas.

\section{Tabel 2. Uji Validitas WFH}

Item-Total Statistics

\begin{tabular}{|l|r|r|r|r|}
\hline & $\begin{array}{c}\text { Scale Mean if } \\
\text { Item Deleted }\end{array}$ & $\begin{array}{r}\text { Scale Variance } \\
\text { if Item Deleted }\end{array}$ & $\begin{array}{c}\text { Corrected Item- } \\
\text { Total } \\
\text { Correlation }\end{array}$ & $\begin{array}{c}\text { Cronbach's } \\
\text { Alpha if Item } \\
\text { Deleted }\end{array}$ \\
\hline X3.1 & 24,61 & 20,758 &, 814 &, 871 \\
X3.2 & 24,32 & 19,794 &, 836 &, 868 \\
X3.3 & 24,56 & 20,786 &, 765 &, 875 \\
X3.4 & 24,53 & 21,066 &, 752 &, 877 \\
X3.5 & 24,69 & 22,791 &, 580 &, 892 \\
X3.6 & 24,83 & 22,306 &, 551 &, 895 \\
X3.7 & 24,79 & 22,112 &, 552 &, 896 \\
X3.8 & 24,82 & 21,485 &, 604 &, 891 \\
\hline
\end{tabular}

Sumber : Hasil Penelitian,2021(Data Diolah)

Berdasarkan Tabel 2 diatas menunjukkan bahwa nilai $\mathrm{r}_{\text {hitung }}$ lebih besar dari 0,30 maka data pada variabel kreativitas dikatakan valid, dan nilai validitas terdapat pada kolom corrected item-Total yang artinya nilai korelasi antara skor setiapbutir dengan skor total pada tabulasi jawaban responden. Sehingga dari masing- masing pertanyaan sebanyak 8 pertanyaan pada ruang lingkup Sekolah Wr Supratman 2. Sehingga data yang diperoleh juga layak untuk digunakan untuk pengujian lebih lanjut yaitu reliabilitas. 
Tabel 3. Uji Validitas Kinerja Guru

Item-Total Statistics

\begin{tabular}{|l|r|r|r|r|}
\hline & $\begin{array}{r}\text { Scale Mean if } \\
\text { Item Deleted }\end{array}$ & $\begin{array}{r}\text { Scale Variance } \\
\text { if Item Deleted }\end{array}$ & $\begin{array}{c}\text { Corrected Item- } \\
\text { Total } \\
\text { Correlation }\end{array}$ & $\begin{array}{c}\text { Cronbach's } \\
\text { Alpha if Item } \\
\text { Deleted }\end{array}$ \\
\hline Y.1 & 28,92 & 18,354 &, 499 &, 812 \\
Y.2 & 29,10 & 18,795 &, 390 &, 826 \\
Y.3 & 29,14 & 18,509 &, 490 &, 813 \\
Y.4 & 29,15 & 17,275 &, 701 &, 787 \\
Y.5 & 29,09 & 16,714 &, 616 &, 795 \\
Y.6 & 29,24 & 15,461 &, 741 &, 775 \\
Y.7 & 28,96 & 18,350 &, 473 &, 815 \\
Y.8 & 28,88 & 17,569 &, 492 &, 814 \\
\hline
\end{tabular}

Sumber : Hasil Penelitian,2021(Data Diolah)

Berdasarkan Tabel 3 diatas menunjukkan bahwa nilai $\mathrm{r}_{\text {hitung }}$ lebih besar dari 0,30 maka data pada variabel kreativitas dikatakan valid, dan nilai validitas terdapat pada kolom corrected item-Total yang artinya nilai korelasi antara skor setiap butir dengan skor total pada tabulasi jawaban responden. Sehingga dari masing- masing pertanyaan sebanyak 8 pertanyaan pada ruang lingkup Sekolah Wr Supratman 2. Sehingga data yang diperoleh juga layak untuk digunakan untuk pengujian lebih lanjut yaitu reliabilitas.

\section{Uji Reliabilitas}

Uji reliabilitas dapat dilakukan secara bersama-sama terhadap seluruh butir pertanyaan, atau dilakukan secara individual dari setiap butir pertanyaan. Jika nilai Cronbach's alpha> 0,6-0,79 maka dikatakan butir pertanyaan tersebut telah reliabel atau andal.

Tabel 4. Uji Reliabilitas Komitmen Reliability Statistics

\begin{tabular}{|r|c|}
\hline \multicolumn{1}{|c|}{ Cronbach's Alpha } & N of Items \\
\hline, 891 & 8 \\
\hline
\end{tabular}

Sumber : Hasil Penelitian,2021(Data Diolah)

Berdasarkan table 4 diatas bahwa hasil output spss diketahui nilai cronbach's alpha nya adalah sebesar 0,891>0,60 sehingga disimpulkan bahwa pertanyaan yang telah diberikan kepada responden yang terdiri dari 8 pertanyaan pada variabel komitmen $\left(\mathrm{X}_{1}\right)$ adalah reliabel atau dapat dikatakan handal.

Tabel 5. Uji Reliabilitas Kreativitas Reliability Statistics

\begin{tabular}{|r|c|}
\hline \multicolumn{1}{|c|}{ Cronbach's Alpha } & N of Items \\
\hline, 891 & \\
\hline
\end{tabular}

Sumber : Hasil Penelitian,2021(Data Diolah)

Berdasarkan table 5 diatas bahwa hasil output spss diketahui nilai cronbach's alpha nya adalah sebesar 0,891>0,60 sehingga disimpulkan bahwa pertanyaan yang telah diberikan kepada responden yang terdiri dari 8 pertanyaan pada variabel kreativitas $\left(\mathrm{X}_{2}\right)$ adalah reliabel atau dapat dikatakan handal. 


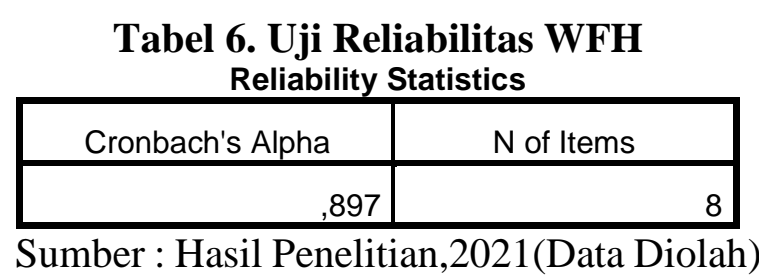

Berdasarkan table 6 diatas bahwa hasil output spss diketahui nilai cronbach's alpha nya adalah sebesar 0,891>0,60 sehingga disimpulkan bahwa pertanyaan yang telah diberikan kepada responden yang terdiri dari 8 pertanyaan pada variable $\mathrm{WFH}\left(\mathrm{X}_{3}\right)$ adalah reliabel atau dapat dikatakan handal.

\section{Tabel 7. Uji Reliabilitas Kinerja Guru} Reliability Statistics

\begin{tabular}{|r|r|}
\hline Cronbach's Alpha & N of Items \\
\hline, 825 & \\
\hline
\end{tabular}

Sumber : Hasil Penelitian,2021(Data Diolah)

Berdasarkan tabel 7 diatas bahwa hasil output spss diketahui nilai cronbach's alpha nya adalah sebesar 0,891>0,60 sehingga disimpulkan bahwa pertanyaan yang telah diberikan kepada responden yang terdiri dari 8 pertanyaan pada variable kinerja guru (Y) adalah reliabel atau dapat dikatakan handal.

\section{Uji Asumsi Klasik}

Uji Normalitas

Uji normalitas bermaksud mendapatkan distribusi data dalam variabel yang akan digunakan dalam penelitian. Berikut hasil uji normalitas dengan analisis grafik histogram, Probability-Plot dan analisis statistik kolmogorov-smirnov.

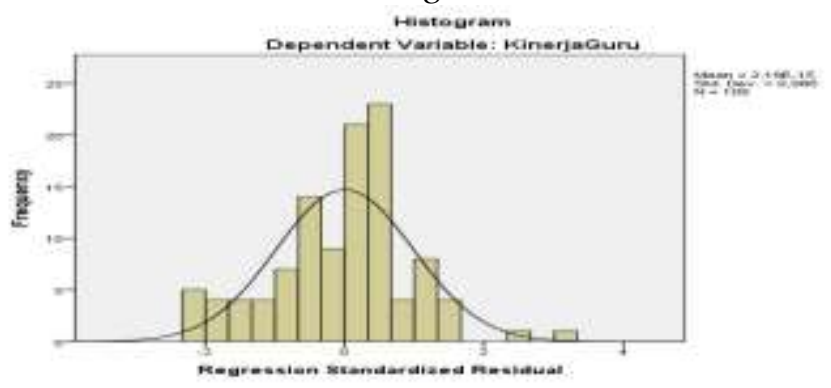

Gambar 1 Uji Normalitas Histogram

Sumber : Hasil Penelitian, 2021 (Data Diolah)

Grafik histogram pada Gambar 1 memperlihatkan bahwa grafik kurva yang sudah condong simetrus (U) dan tidak melenceng kekiri maupun melenceng kekanan sehingga dapat dinyatakan bahwa data telah berdistribusi normal.

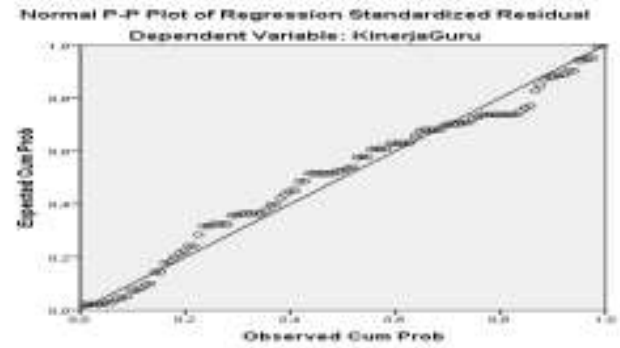

Gambar 2 Uji Normalitas P-Plot

Sumber : Hasil Penelitian,2021 (Data Diolah) 
Grafik normalitas P-Plot diatas, dilihat bahwa data sudah menyebar mengikuti garis diagonal. Penyebarannya hampir sudah seluruh mendekati garis diagonal. Hal ini menunjukkan bahwa grafik P-Plot sudah berdistribusi normal.

Tabel 8. Uji Normalitas Kolmogorov-Smirnov One-Sample Kolmogorov-Smirnov Test

\begin{tabular}{|ll|r|}
\hline & & Unstandardized Residual \\
\hline N & & 109 \\
Normal Parameters & Mean &, 0000000 \\
& Std. Deviation & 1,46932413 \\
& Absolute &, 095 \\
Most Extreme Differences &, 095 \\
& Positive &,- 085 \\
Kolmogorov-Smirnov Z & Negative &, 987 \\
Asymp. Sig. (2-tailed) & &, 284 \\
\hline
\end{tabular}

a. Test distribution is Normal.

b. Calculated from data.

Sumber : Hasil Penelitian, 2021 (Data Diolah)

Hasil uji normalitas kolmogorov-smirnov menunjukkan bahwa nilai signifikan sebesar 0,284 > 0,05 dengandemikian bahwa data tersebut telah berdistribusi normal.

\section{Uji Multikolinieritas}

mengungkapkan uji ini memiliki tujuan dalam mengukur apa model regresi didapati adanya kolerasi diantara variabel bebas (independen).

Tabel 9. Uji Multikolinieritas Coefficients $^{\mathrm{a}}$

\begin{tabular}{|c|c|c|c|}
\hline \multirow{2}{*}{\multicolumn{2}{|c|}{ Model }} & \multicolumn{2}{|c|}{ Collinearity Statistics } \\
\hline & & Tolerance & VIF \\
\hline & Komitmen & ,220 & 4,542 \\
\hline & Kreativitas & ,143 & 6,980 \\
\hline & WFH & , 161 & 6,196 \\
\hline
\end{tabular}

Nilai VIF variabel bebas komitmen sebesar 4,542, kreativitas sebesar 6,980 dan WFH sebesar 6,196 ketiga variabel tersebut memiliki nilai dibawah 10 dan nilai tolerance berada diatas 0,1 yaitu pada variabel bebas komitmen sebesar 0,220, kreativitas sebesar 0,143 dan WFH sebesar 0,161. Sehingga tidak terjadi gejala multikolinieritas.

\section{Uji Heteroskedastisitas}

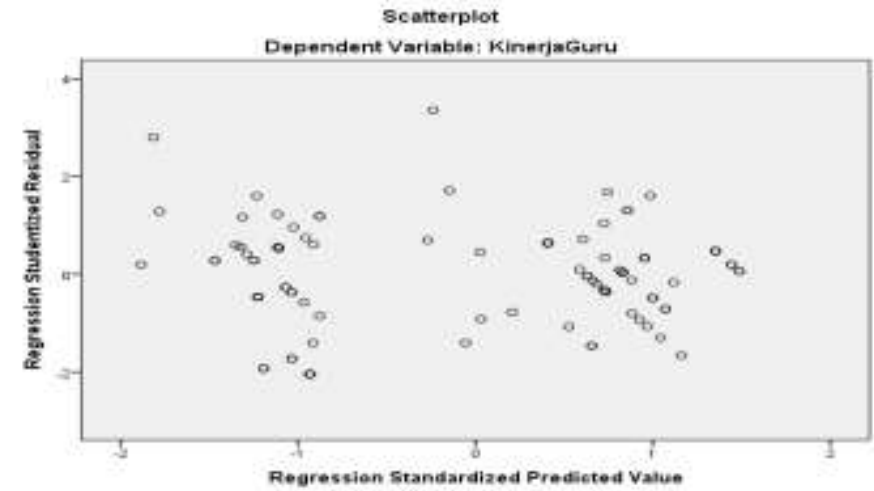

Gambar 3 Uji Heteroskedastisitas

Sumber : Hasil Penelitian, 2021 (Data Diolah) 
Berdasarkan garfik scatterplot tampak bintik-bintik memencar dengan pola yang sudah teratur baik diatas maupun dibawah angka (0) pada sumbu Y dan tidak bergerombol di satu tempat, maka dari grafik diatas dapat disimpulkan bahwa tidak terjadi heteroskedastisitas.

Uji heteroskedastisitas juga dapat dilihat dengan menggunakan uji glejser yang jika nilai signifikan nya diatas 0,05 maka tidak terjadi heteroskedastisitas.

\section{Tabel 10. Uji Glejser}

Coefficients $^{\mathrm{a}}$

\begin{tabular}{|c|c|c|c|c|c|c|}
\hline \multirow{2}{*}{\multicolumn{2}{|c|}{ Model }} & \multicolumn{2}{|c|}{ Unstandardized Coefficients } & \multirow{2}{*}{$\begin{array}{c}\text { Standardized } \\
\text { Coefficients }\end{array}$} & \multirow[t]{2}{*}{$\mathrm{t}$} & \multirow[t]{2}{*}{ Sig. } \\
\hline & & B & Std. Error & & & \\
\hline \multirow{4}{*}{1} & (Constant) & 2,767 &, 497 & & 5,563 &, 000 \\
\hline & Komitmen &,- 014 & ,036 &,- 074 &,- 379 & ,705 \\
\hline & Kreativitas &,- 081 & ,041 &,- 472 & $-1,959$ & ,053 \\
\hline & WFH & ,038 & ,041 & ,209 &, 921 & ,359 \\
\hline
\end{tabular}

a. Dependent Variable: ABRESID

Sumber : Hasil Penelitian, 2021 (Data Diolah)

Hasil uji glejser di Tabel 10 menunjukkan bahwa variabel komitmen memiliki nilai signifikan sebesar 0,705, variabel kreativitas sebesar 0,053 dan WFH sebesar 0,359>0,05. Sehingga dapat ditarik kesimpulan bahwa hasil uji glejser tidak terjadi heteroskedastisitas.

\section{Hasil Analisis Data}

\section{Model Penelitian}

Pengujian hipotesis menggunakan analisis linear berganda. Model regresinya adalah sebagai berikut :

Tabel 13. Hasil Analisis Linear Berganda Coefficients $^{\mathrm{a}}$

\begin{tabular}{|c|c|c|c|c|c|c|}
\hline \multirow{2}{*}{\multicolumn{2}{|c|}{ Model }} & \multicolumn{2}{|c|}{ Unstandardized Coefficients } & \multirow{2}{*}{$\begin{array}{c}\begin{array}{c}\text { Standardized } \\
\text { Coefficients }\end{array} \\
\text { Beta }\end{array}$} & \multirow[t]{2}{*}{$\mathrm{t}$} & \multirow[t]{2}{*}{ Sig. } \\
\hline & & B & Std. Error & & & \\
\hline \multirow{4}{*}{1} & (Constant) & 8,145 & ,828 & & 9,840 & ,000 \\
\hline & Komitmen & ,177 &, 060 &, 1 & 2,953 & ,004 \\
\hline & Kreativitas & ,201 & ,069 & 2 & 2,916 &, 004 \\
\hline & WFH &, 508 & ,068 &, 5 & 7,464 &, 000 \\
\hline
\end{tabular}

a. Dependent Variable: KinerjaGuru

Sumber : Hasil Penelitian, 2021 (Data Diolah)

Kinerja Guru = 8,145 + 0,177 Komitmen + 0,201 Kreativitas + 0,508 WFH

Makna dari persamaan regresi linear berganda diatas adalah :

1. Nilai konstanta sebesar 8,145 yang menunjukkan variabel komitmen, kreativitas dan WFH dianggap nol (0) maka kinerja guru Y sebesar 8,145.

2. Nilai satuan regresi komitmen sebesar 0,177 menyatakan bahwa setiap kenaikan komitmen 1\%, maka kinerja guru (Y) akan mengalami kenaikan sebesar 0,177 satuan.

3. Nilai satuan regresi kreativitas sebesar 0,201 menyatakan bahwa setiap kenaikan kreativitas 1\%, maka kinerja guru (Y) akan mengalami kenaikan sebesar 0,201 satuan.

4. Nilai satuan regresi WFH sebesar 0,508 menyatakan bahwa setiap kenaikan WFH $1 \%$, maka kinerja guru (Y) akan mengalami kenaikan sebesar 0,508 satuan. 


\section{Koefisien Determinasi $\left(\mathbf{R}^{2}\right)$}

Koefisien determinasi Adjusted $R$ Square bertujuan untuk menghitung sejauh mana kemampuan model untuk menjelaskan variabel yang bebas.

Tabel 11. Uji Koefisien Determinasi

Model Summary

\begin{tabular}{|l|r|r|r|r|}
\hline Model & \multicolumn{1}{|c|}{$\mathrm{R}$} & $\mathrm{R}$ Square & \multicolumn{1}{c|}{$\begin{array}{c}\text { Adjusted } \mathrm{R} \\
\text { Square }\end{array}$} & $\begin{array}{c}\text { Std. Error of the } \\
\text { Estimate }\end{array}$ \\
\hline 1 &, $951^{\mathrm{a}}$ &, 904 &, 901 & 1,490 \\
\hline
\end{tabular}

a. Predictors: (Constant), WFH, Komitmen, Kreativitas

b. Dependent Variable: KinerjaGuru

Sumber : Hasil Penelitian, 2021 (Data Diolah)

Nilai adjusted $r$ square ini adalah sebesar 0,901 atau sebesar $90,1 \%$ yang artinya bahwa komitmen, kreativitas dan WFH hanya menjelaskan variasi variabel kinerja guru sebesar $90,1 \%$ dan sisanya 9,9\% dipengaruhi oleh variabel lain diluar variabel penelitian ini.

\section{Pengujian Hipotesis Secara Simultaj (Uji F)}

Uji statistik F umumnya memperlihatkan apakah seluruh variabel bebasa yang masuk ke dalam model memiliki pengaruh secara simultan bagi variabel terikat.

Tabel 12. Uji Simultan (Uji F) ANOVA $^{\mathrm{a}}$

\begin{tabular}{|rl|r|r|r|r|r|}
\hline Model & & Sum of Squares & \multicolumn{1}{|c|}{ Df } & Mean Square & \multicolumn{1}{c|}{ F } & Sig. \\
\hline \multirow{4}{*}{1} & Regression & 2192,984 & 3 & 730,995 & 329,188 &, $000^{\circ}$ \\
& Residual & 233,163 & 105 & 2,221 & & \\
& Total & 2426,147 & 108 & & & \\
\hline
\end{tabular}

a. Dependent Variable: KinerjaGuru

b. Predictors: (Constant), WFH, Komitmen, Kreativitas

Sumber : Hasil Penelitian, 2021 (Data Diolah)

Dalam uji ini hasil dari $\mathrm{F}_{\text {hitung }}$ adalah sebesar 329,188 dan $\mathrm{F}_{\text {tabel }}$ adalah sebesar 2,69 yang artinya adalah $F_{\text {hitung }}>F_{\text {tabel }}$ sebesar 329,188 $>2,69$ dengan taraf signifikan 0,000< 0,05 maka $\mathrm{H}_{0}$ ditolak dan $\mathrm{H}_{\mathrm{a}}$ diterima sehingga diambil kesimpulan bahwa komitmen, kreativitas dan WFH berpengaruh dan signifikan secara bersama-sama terhadap kinerja guru Wr Supratman 2.

\section{Pengujian Hipotesis Secara Parsial (Uji t)}

Pengujian statistik t pada umunya membutikan sejauh apa pengaruh suatu variabel penjelas atau terikat dengan individual untuk menjelaskan variasi variabel bebas.

Tabel 13. Uji Parsial (Uji t)

Coefficients $^{\mathrm{a}}$

\begin{tabular}{|c|c|c|c|c|c|c|}
\hline \multirow{2}{*}{\multicolumn{2}{|c|}{ Model }} & \multicolumn{2}{|c|}{ Unstandardized Coefficients } & \multirow{2}{*}{$\begin{array}{c}\text { Standardized Coefficients } \\
\text { Beta }\end{array}$} & \multirow[t]{2}{*}{$\mathrm{T}$} & \multirow[t]{2}{*}{ Sig. } \\
\hline & & B & Std. Error & & & \\
\hline \multirow{4}{*}{1} & (Constant) & 8,145 & ,828 & & 9,840 &, 000 \\
\hline & Komitmen & ,177 & ,060 & , 190 & 2,953 & ,004 \\
\hline & Kreativitas & 201 & ,069 & ,233 & 2,916 &, 004 \\
\hline & WFH & ,508 & ,068 & ,562 & 7,464 &, 000 \\
\hline
\end{tabular}

a. Dependent Variable: KinerjaGuru

Sumber : Hasil Penelitian, 2021 (Data Diolah) 
Dari hasil uji t tabel di atas menyatakan bahwa

1. Variabel komitmen memiliki nilai $t_{\text {hitung }}$ sebesar 2,953 dan $t_{\text {tabel }}$ sebesar 1,65950 yang berarti bahwa $t_{\text {hitung }}>t_{\text {tabel }}$ yaitu 2,953 $>1,65950$ dengan taraf signifikan $0,004<0,05$ yang berarti $\mathrm{H}_{0}$ ditolak dan $\mathrm{H}_{\mathrm{a}}$ diterima artinya adalah komitmen berpengaruh secara parsial terhadap kinerja guru Wr Supratman 2.

2. Variabel kreativitas memiliki nilai $t_{\text {hitung }}$ sebesar 2,916 dan $t_{\text {tabel }}$ sebesar 1,65950 yang berarti bahwa $t_{\text {hitung }}>t_{\text {tabel }}$ yaitu 2,916 $>1,65950$ dengan taraf signifikan $0,004<0,05$ yang berarti $\mathrm{H}_{0}$ ditolak dan $\mathrm{H}_{\mathrm{a}}$ diterima artinya adalah kreativitas berpengaruh secara parsial terhadap kinerja guru Wr Supratman 2.

3. Variabel WFH memiliki nilai $t_{\text {hitung }}$ sebesar 7,464 dan $t_{\text {tabel }}$ sebesar 1,65950 yang berarti bahwa $\mathrm{t}_{\text {hitung }}>\mathrm{t}_{\text {tabel }}$ yaitu 7,464 $>1,65950$ dengan taraf signifikan $0,000<0,05$ yang berarti $\mathrm{H}_{0}$ ditolak dan $\mathrm{H}_{\mathrm{a}}$ diterima artinya adalah WFH berpengaruh positif dan signifikan secara parsial terhadap kinerja guru Wr Supratman 2.

\section{Pembahasan}

\section{Pengaruh Komitmen Terhadap Kinerja Guru}

Hasil pengujian hipotesis secara parsial dilihat bahwa nilai thitung sebesar 2,953 dengan taraf siginifikan sebesar $0,004<0,05$. Nilia thitung $>$ nilai ttabel atau 2,953 $>1,65950$, maka hipotesis pertama dapat diterima yaitu komitmen berpengaruh positif dan signifikan secara parsial terhdap kinerja karyawan Wr Supratman 2 Medan.

Hasil penelitian ini sejalan dengan penelitian yang dilakukan oleh Gibson (2017:214), komitmen organisasi sebagai tingkatan dari individu mendefenisikan dri dan terlibat dalam organisasi yang diikuti dan tidak ada keinginan untuk meningkatkannya. Untuk dapat menghasilkan kinerja yang baik seorang karyawan harus memiliki komitmen yang tinggi pada organisasinya.

Kinerja guru merupakan unjuk kerja yang dilakukan oleh guru dalam melaksanakan tugasnya sebagai pendidik. Kualitas kinerja guru akan sangat menentukan pada kualitas hasil pendidikan karena guru banyak bersentuhan langsung dengan peserta didik dalam proses pembelajaran di lembaga pendidikan. Adanya komitmen akan meningkatkan kinerja dan mendorong individu aktif terlibat dalam berbagai masalah penting dalam organisasi. Keinginan untuk mengembangkan kompetensi pribadi yang dapat memberikan kontribusi berarti bagi organisasi akan muncul apabila individu punya komitmen yang kuat. Dengan adanya komitmen yang kuat pada pribadi guru, maka kinerja guru akan meningkat dan semakin kuatnya keinginan guru untuk tetap berada pada sekolah.

\section{Pengaruh Kreativitas Terhadap Kinerja Guru}

Hasil pengujian hipotesis secara parsial dilihat bahwa nilai thitung sebesar 2,916 dengan taraf siginifikan sebesar 0,004 $<0,05$. Nilia thitung > nilai ttabel atau 2,916 $>1,65950$, maka hipotesis kedua dapat diterima yaitu komitmen berpengaruh positif dan signifikan secara parsial terhdap kinerja karyawan Wr Supratman 2 Medan.

Hasil penelitian ini sejalan dengan penelitian yang dilakukan oleh Sabrin (2011:62), Semakin tinggi kretaivitas peserta didik, maka semakin besar pula peluangnya untuk mencapai tujuan dari pendidikan. Hasil belajar yang diperoleh siswa sangat berkaitan erat dengan kreativitas yang dimilikinya.

Kreativitas guru perlu dikembangkan agar diperoleh kinerja yang lebih optimal, karena kreativitas merupakan dimensi kemampuan manusia dalam mengembangkan ilmu pengetahuan dan teknologi, serta dimensi yang memberi ciri keunggulan bagi pertumbuhan diri individu yang sehat, produktif, dan inovatif. Dengan demikian, temuan ini memberikan 
bukti empirikbahwa makin tinggi kreativitasmakin tinggi pula kinerja guru WR Supratman.

\section{Pengaruh WFH Terhadap Kinerja Guru}

Hasil pengujian hipotesis secara parsial dilihat bahwa nilai thitung sebesar 7,464 dengan taraf siginifikan sebesar $0,004<0,05$. Nilia thitung $>$ nilai ttabel atau 7,464 $>1,65950$, maka hipotesis ketiga dapat diterima yaitu WFH berpengaruh positif dan signifikan secara parsial terhdap kinerja karyawan Wr Supratman 2 Medan.

Hasil penelitian ini sejalan dengan penelitian yang dilakukan oleh Arwen,dkk (2020), bahwa dampak belajar dirumah juga dirasakan oleh orang tua juga memiliki beban lebih karena harus menjadi guru dirumah, mengajar membuat tugas dan selalu memantau.

Pelaksanaaan WFH dapat menghemat pengeluaran yaitu mengurangi biaya transportasi guru dari rumah ke sekolahan sehingga menghemat biaya, dengan WFH para guru juga akan memiliki sedikit waktu luang untuk mengerjakan pekerjaan lainnya di rumah, mereka bisa melaksanakan aktivitas keluarga dan pekerjaaan sampingan lainnya. Sedangkan dampak negatif dari WFH yaitu membuat guru menjadi jenuh bekerja di rumah dengan suasana kerja yang monoton, WFH juga telahmengurangi interaksi guru dengan teman guru dan peserta didik dan lingkungan sekolah, WFH juga memungkinkan akan menurunkan kualitas proses belajar mengajar karena tidak adanya interaksi langsung selama pross belajar mengajar antara guru dengan peserta didik, WFH membuat guru tidak fokus bekerja karena adanya interaksi dengan anggota keluarganya saat bekerja. Peneliti memberikan beberapa saran yaitu selama WFH pihak terkait menyediakan sarana prasarana seperti kuota internet dan materi materi pembelajaran online.

\section{SIMPULAN DAN SARAN}

\section{Simpulan}

1. Hasil pengujian hipotesis secara parsial dilihat bahwa nilai $t_{\text {hitung }}$ sebesar 2,953 dengan taraf siginifikan sebesar $0,004<0,05$. Nilia $t_{\text {hitung }}>$ nilai $t_{\text {tabel }}$ atau 2,953>1,65950, maka hipotesis pertama dapat diterima yaitu komitmen berpengaruh positif dan signifikan secara parsial terhdap kinerja karyawan WR Supratman Medan.

2. Hasil pengujian hipotesis secara parsial dilihat bahwa nilai $t_{\text {hitung }}$ sebesar 2,916dengan taraf siginifikan sebesar $0,004<0,05$. Nilia $t_{\text {hitung }}>$ nilai $t_{\text {tabel }}$ atau 2,916>1,65950, maka hipotesis kedua dapat diterima yaitu kreativitas berpengaruh positif dan signifikan secara parsial terhdap kinerja karyawan WR Supratman Medan.

3. Hasil pengujian hipotesis secara parsial dilihat bahwa nilai $t_{\text {hitung }}$ sebesar7,464 dengan taraf siginifikan sebesar $0,004<0,05$. Nilia $t_{\text {hitung }}>$ nilai $t_{\text {tabel }}$ atau 7,464 >1,65950, maka hipotesis Ketiga dapat diterima yaitu WFH berpengaruh positif dan signifikan secara parsial terhdap kinerja karyawan WR Supratman Medan.

4. Hasil pengujian hipotesis secara simultan dilihat bahwa nilai $F_{\text {hitung }}$ sebesar 329,188 dengan taraf siginifikan sebesar $0,000<0,05$. Nilia $F_{\text {hitung }}>$ nilai $F_{\text {tabel }}$ atau 329,188 $>2,69$, maka hipotesis dapat diterima yaitu komitmen, kreativitas dan WFH berpengaruh positif dan signifikan secara Simultan terhdap kinerja karyawan WR Supratman Medan.

\section{Saran}

Bagi Peneliti Selanjutnya, Disarankan untuk lebih memperbanyak variabel lain diluar dari variabel yang diteliti oleh peneliti seperti, motivasi, inovasi dan kompetensi.

Bagi Yayasan WR Supratman Medan Tetap menjaga komitmen yang telah di terapkan, meningkatkan kreativitas dalam diri seorang guru dan meningkatkan tingkat pembalajaran selama masa pandemi Covid 19 ini agar proses belajar mengajar akan tetap 
berjalan dengan baik sehingga kinerja guru yang diberikan akan meningkat dengan baik pula.

\section{DAFTAR PUSTAKA}

Cicilia Tri Suci Rokhani. 2020. Pengaruh Work From Home (WFH) Terhadap Kinerja Guru SD Negeri Dengkek 01 Pati Selama Masa Pandemi Covid-19. ISSN 27164445, Vol 2 No 1

Desri Arwen. 2020. Student Learning Motivation Influences The Development Of The Corona Virus Pandemic (COVID 19). International Journal of Advanced Science and Technology, 29 (9s), $4911 \quad$ - 4925. Retrieved from http://sersc.org/journals/index.php/IJAST/ article/view/17339

Edy, Sutrisno. 2016. Manajemen Sumber Daya Manusia. Kencana Prenada Media Group, Jakarta

Evi Suriyani. 2014. Pengaruh Kompetensi dan Komitmen Terhadap Kinerja Guru SMA Negeri 1 Bunut Pelalawan. Jom Fekon, Vol 2 No 1

Gądecki, J., Jewdokimow, M., \& Żadkowska, M. 2018. New technologies and family life in the context of work at home. The strategies of work-life balance. Studia Humanistyczne AGH, 17(4), 77. https://doi.org/10.7494/human.2018.17.4.77

Gibson. 2017. Organization, Behavior, Structure \& Process. edition 10. Boston. USA

Ghozali, Irham. 2016. Aplikasi Analisis Multivariete. Cetakan VIII. Semarang : Badan Penerbit Universitas Diponegoro

Hamzah., \& Nurdin 2011. Belajar dengan Pendekatan PAILKEM. Jakarta: PT Bumi Aksara

Joharis.2019. Komitmen Membangun Pendidikan (Tinjauan Krisis Hingga Perbaikan Menurut Teori). PUSDIKRA Advertising. CV Widya Puspita, Medan

Lamya Hayatina. 2019. Pengaruh Kreativitas dan Kedisiplinan Terhadap Kinerja Guru(Studi Kasus Terhadap SMK Manba'ul Ulum Cirebon). ISSN 2599-0470, Vol 2 No 2

Lasalu, N., F. M. Sahami., dan F, Kasim. 2015. Komposisi dan Keanekaragaman Gastropoda Ekosistem Mangrove di Wilayah Pesisir Teluk Tomini sekitar Desa Tabulo Selatan Kecamatan Mananggu Kabupaten Boalemo Provinsi Gorontalo. Jurnal Ilmiah Perikanan dan Kelautan. Vol. 3 Nomor 1

Muliawan, Jasa Ungguh. 2016. Mengambangkan Imajinasi dan Kreatifitas Anak. Yogyakarta : Gava Media.

Ratna Setyowati Putri, dkk. 2020. Impact of the COVID-19 Pandemic on Online Home Learning: An Explorative Study of Primary Schools in Indonesia. International Journal of Advanced Science and Technology, 29(05), 4809 - 4818. Retrieved from http://sersc.org/journals/index.php/IJAST/ article/view/13867

Sugiyono. 2013. Metode Penelitian Kuantitatif, Kualitatif dan R\&D. Bandung : Afabeta

Sujarweni, V. Wiratna. 2014. Metode Penelitian: Lengkap, Praktis, dan Mudah Dipahami. Yogyakarta: Pustaka Baru Press

Supardi. 2014. Kinerja Guru. Jakarta: PT Raja Grafindo Persada

Wibowo. 2016. Manajemen Kinerja. Edisi Kelima, PT.Rajagrafindo Persada Jakarta 14240 